\author{
Dr. Gudrun Kuschke \\ Departement German, Potchefstroom University for C.H.E.
}

\title{
POETRY AND ETHOS: TOWARD AN ONTIC UNDERSTANDING
}

\section{THE ANALYTIC QUEST}

This bricl interpretative study endeavours to explicate and illustrate a normative method of poetic: analysis. By means of this integrated struchural system, the reader has an authoritative standard at his disposial. While the reader is completely free to apply these directives subjectively, the objective, religiously-lounded philosophical basis keeps the danger ol pure inspiralional analysis at bay.

Each aspect of creational reality is considered in its own arl istic right and ohe interrelation of the parts continually reassesses the signilicance of the individual segments. It is nevertheless the coherent mity of the text that remains central to the reading and understanding of the work of art.

'This artistic wholeness is the interpretative expression of the authorial presence in the poem. The quest of this integrated approach is 10 analyse and evaluate such an acsthetic interpretation of reality, and only by unlocking the manifested expression of the artist, can the reacler truly penetrate into the "heartbeat" of the aresthet ic experience.

\section{AESTHETIC ETHOS}

As art, or any aesthetic experience, is always an interpretation, a particular view of reality, it is important to gain insight into such a portrayed vision. A system should therefore be devised by which to detemine and evaluate the expression of the artisı's insight, his feeling and his sense of beauty, his imagination and his sulpectivity (Rookmaaker, 1975: 229) ; in short, Ihe reflection of the spirit of man and spirit of the times.

It is this spirit permeating the experience, the human experience recrealed

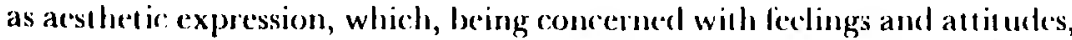
also relleces the "lived fulness of the world" (Brooks \& Warren, 1976: 9).

And yet the spitit ol a poem does not exist "an sich", but is only recognizable: in the "Being" of the poem, the aesthet ic espression. In onher words, the 


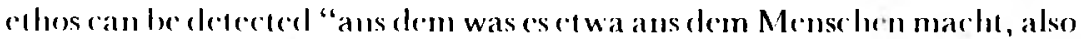
aus dem (iestalthatten uncl (iestaltgewordenen" (Schmeider, 1956: 8).

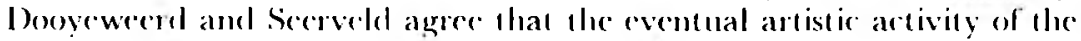
art ist is religionsly determined and dieceded from the heart (Van der Breng, 1975: IGif). Il artist ic expression is indecel groumded in lhe" "supra-structural

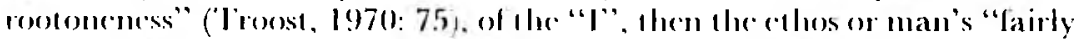
constant foumblational at il ude" (Troosi: 77) towards lile, must be cvinced in a recognizable and analysable expression.

Detection of the objectilied cthes must, like any seientilic experiment, be lounded upon law-bonnd analysis in order to be normative. (Christian philosophy and scripture can provide such a basis. I shall attempt to clucielate this point of cleparture briedly.

Both ( ihrist ian philosophy and scriptural truth place the religious conecont ration of hmman existence in the herat of man on the "l" ('Troost: 72). The confessional wituess of man or poem linds its point of departure in the same root. This " $I$ " is concretely expressed through human acts and their modal aspects, which are callecl into existence by human posit izat ion of norm-laws through ares. These acts al ways have their origin in the integrated centere of life, in the "I" which caunot be analysed except in the expression of the selfhood through the choss.

Troost (1958: 372) sees the recognizahle manifistation ol the erlues in lile and crlente, as the expression of the internal intention, springing fiom the human "l". The ethos is thus a total rellection of the religious direction of man's life, of all interhuman and all other melationships and also of his cullual ancefacts. This implies that the ethos of a poem can also be determined through the reverse approach; from the poem to the ethos.

\section{THROUGH STYLE TO SPIRIT}

for Secrveld the art istic expression is visil, in the style of the literary work and signilicantly enough, it is the whole mat, wilh his whole modal make11). Who is "subtcrancianly" involved (1977: 41).

It is the totality of the poem, the coherent integration of the parts that will be reflected through the style of the literary work. Although cach aspect of reality has its own expressive importance and relevance. it is only the interrelatedness, colherenee and climensionality which will reveal the greatness of the poctic vision. It is this acsthetic vision which lends signilicance to the meaning of a poem, this "credal statemen" (Rookmataker, 1975: 114), integrated in the lotality of the poem, which will be the

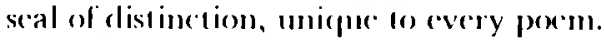


()nly by reading and unclerstanding ant in this way can we share in another

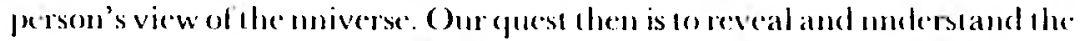
literatly testimony of the learted "l".

\section{AN INTEGRATED METHODOLOGY*}

'The structural framework used in the analysis ol the following pone, is

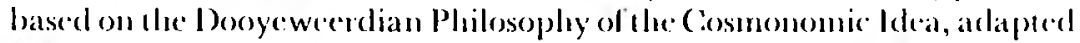
for the plastic or line arts hy Rookmakere and for literature ly calvin Sicervelil.

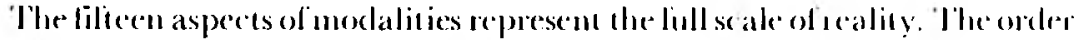
of the modalities has been adjusted and the positivalions have heen speceilically devised with the purpose of attempting a practical, integrated analysis ol poetry in particular.

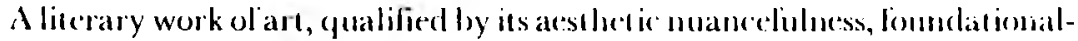
ly exists through the word. It is the lingual base, acshledically opened up and pistically envisioned, hat unfolds ole literary possibilities of poetry.

In suel an integrated approach to art, the lollowing levels ol analysis (:an lue distinguished: the constituent lingua-fommative aspeces, the allunent atesthelic gualitice and llee pistic qualities of a work of alt.

\subsection{The lingua-formative basis}

T'he surface level ol analysis, fomded on the lingual aspect, imeoportates the lisst minc adaped moclalities (from the numerical to the lingual). This lirst phase of the first-level analysis (close reading) will begiu with the positivization of the numerical aspere and progess towards the lingual foundation. These lingua-formative aspects are simply defined lrom the $10 \times 1$ without interpretative deductions.

4.1.1 The interpretative level of the lingua-lomative analysis is opened up by the aesthetic coulilying linnetion and thus recpuices an atesthetic reassessment of the sub-layer (1-9) and its latent secondary possibilitics.

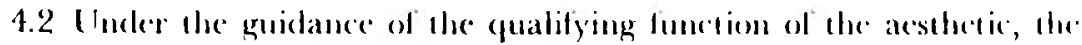
higher aspeces of a work of art are unlolded and revealed in their many-

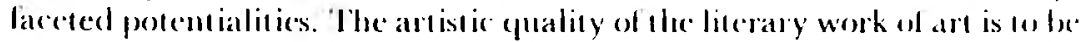
detemined in direce comelation with the manner in which symbolicat

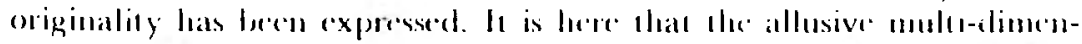

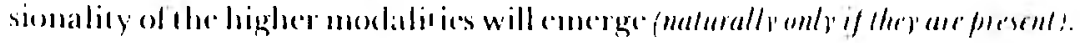

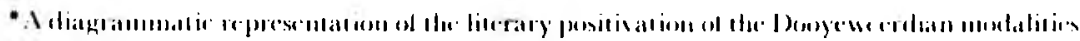

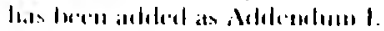


4.3 The confessional stance of the artist will become evielent in the expression of the cthos of the artistic manifestation. This is the crux of this literary amalysis.

By means of the leading function of the conlessional aspect in the whole mofolding process of analysis, the various parts and their appropriate balance will be unlorked and evaluated.

By means of these various segments, man's decpest convictions may be implicitly or explicilly discovered and incerpeted. This then is the moment when the message of the aestheric meaning attains its micfucuess; the

\section{STRUCTURAL ANALYSIS}

Becanse of limitations of space only one poem will be analysed according 10 the integrated methodology explicated. Only three of the fiftecn aspects will be analysed but they will alrearly give a clear indication of the climensionality revealcel by this medhod as well as the confessional witness pervading the poem as a whole.

The poem hrezigung by Raner Maria Rilke* is not purely fictitious but relies on an historical reality recorded in the Gospels. What the poet makes of the event and how it is expressed, is the concen of this analysis.

We shall consider the fouth, lifh and enth aspects; thus, the physical, biotic and the aesthetic modalities positivized in the poem.

\subsection{The physical aspect}

The positivizations for this modality are: sound, rhyme, tension and acsthet ir balance.

5.1.1 On the surface level of the first level reading, which does not allempl any interpretation jel, a predominance of the heavier, long $a, a, u$ and o voresels is to be detected. Three comsonamial soumd pallerms can be distinguished: the fricative "l,", gultural "(") and the sibilant "sch". They do not only reflect a puphonious uerse but, antiripatonily add to the force of expression of the following aspect, the biotic and thus sound is fussed to the other dimensioms of expression. The rhyme scheme showes a correlation of the first, last and second and third stamzas. The fourth stanza has a signilicamt fifih line added.

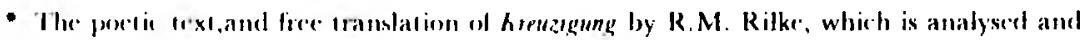
disc usserl in this payer, has been inclueled as .lddrndum 2. 
Ol the thee sound patterns, the strongly represented fricative "L." redlects a narrative continuity (undertined by the repetitive use of "und" at hie beginning of 5 verses): "Kahlen Galgenplat ze/Gesindel/lessen . Alle voller l.ust/hichen, verlalle/Lssiggalle" and also conveys a certain sense of bewildered unreality ("irgend ein Gesindel und es war ihm selber, cr hälte ihn den Elia rufen hören/sie hofften noch ein ganzes Spicl und vielleich den kommenden Elia"), an atmosphere of insensibility in the monotony of the repetitive labials, which suggests a passive surrender to circumstance, a pawn-like quality. Even the diction hints at a rertain automaticily of action:

Lẩngst geübt ... ein Gesindel hinzudrängen

liessen sich ... hängen

dann und wann ... kehrend

liessen sich ... schlenkern

Bis der eine ... sagte.

In contrast to the lulling continuity of the labial sounds, the harsh guttural "G" and the related "ng" sound introduce a tensile clement of stress. "The deceptive calm of the visual and auditory scenario strives to portray the enactment of just another spectarle, distanced as a play on a stage.

The polarized interplay between the soothing " $L$ " and the grating " $(7$ " sounds secms like an onomatopoeic undereurrent, straining uncertainly to and fro; very much like the ontooker's eye (discussed under the biot ic aspect) surveying the scene.

This tensile quality of breathless expectation and fatalistic unbelief is particularly noticeable in the second hall of the poem. The monosyllabic quest ion "Welcher?", draws the attention to the single main higure and the expectation of a spectacular miracle (lines 12 \& 13). The crowd titerally hold their breath but the onlooking-speaker, who seems to have been drawn into this suspense-tilled moment, abruptly appears to alter the trend of narration and reports:

"Alke

hiclten (den dlem: my italies)

gierig ihm die lissiggalle (dass

"r nicht verfalle)"

In line 18, expectation still runs high in "sie holfen noch ein ganres Spiel", which is then finally forced to a conclusive collapse of all hope by the use of 
llee past lense word "verficl". This vacillation between the unspoken question "Will He or won't Ile?", is a personal authorial struggle reflected throughout the pocm.

The presence of the word " "god", which is never explicitly mentioned, is implied in the cummlative use of the "(;" sound. Scripturally this also coincides with fesus" cry: "Nlein Gotl, mein Goll, warum hast du mich verlassen?" (Mark 15:34) and the poetic representation in "dic hielten ... gierig ihm die Essiggalle".

The signilicance of the inserted fifth line in the lourth stanza: "uncl sie hicleen, dass er nicht verlalle", which rhymes with "Essiggalle" in the next line, is conclueled in the linality of the past tense "verlicl", the last word of the porm. These rhyming words alrearly indicate an important disclosure concerning a he sent iments of the crowd and of the implied author (the hope of survival and the concrete collapse). Everything disintegrates with the death of ('he ist, the unnamed central figure. The additional line sums up the desperate elfort and hope of the masses to prevent Christ from really dying like any other person; and the conditional verb "verlalle" (which convincingly emplasizes th is hopeful expectation), indicates more than the mere dying of the body.

\subsection{The biotic aspect}

Here the positivation of this modality includes: intensity, climaxing development, forece of expression and vitality.

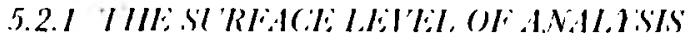

If a work of art has vitality, Woltcrstorff (1978: 314) considers it to possess aesthetic intensity. In this poem the narative quality at lains a developmental vitality in its stressed intial thyme. The interrelatedness of the various modalities, which is continually revealed by means ol the integrated method of analysis, is evident in the retrocipatory comelation of progressive vitality and the vacillating sound quality of the previous physical aspect.

The stressed initial rhyme emphasizes the aspect of time and place in the porm:

'I,ängst' : time

'dann und wann' : time

'Aber oben' : place

'Bis' : implying extension in time and space 
'mul/und/und' : narrative contimuity

'I Mun' : conjunctive dependence on linte and situation

'Alere hinten' : place

'und' : contimuity in lime

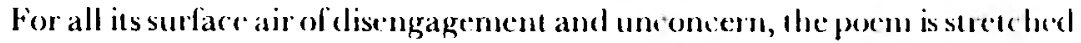
light with inner strugghe, all the more intense for the desperate altempl at disinterestedness. Man's experience and the expression thereof are placed in a spatial dimension and a particular time-relevance. 'The lime distance of the legginning, experienced as if from onemory, as well as the spatial distance of the conchusion, sinultancously express a psychic distance from the event. lime secms to have lost its relevance becanse this event took place "linten ferme", beyond any concern for time.

\section{Climactic movement}

'The event of the crucifixion is marrated from the vantage point of ale onlooker and lis particular confessional stance; thus from the onleokerto the event.

On the surface there are no obvious chimaxes. In word, thought and action there seem to be only disinterested narration and observation. The cry of Mary creates a faint llickering of int erest just to sollapse into the ash that the linal "vertiel" symbolizes.

\subsubsection{INIERPRET.1TIIE LAVEL}

The narration is one of elimactic sweeps of the eye firom the onlooker to the event which is at the place of the skult.

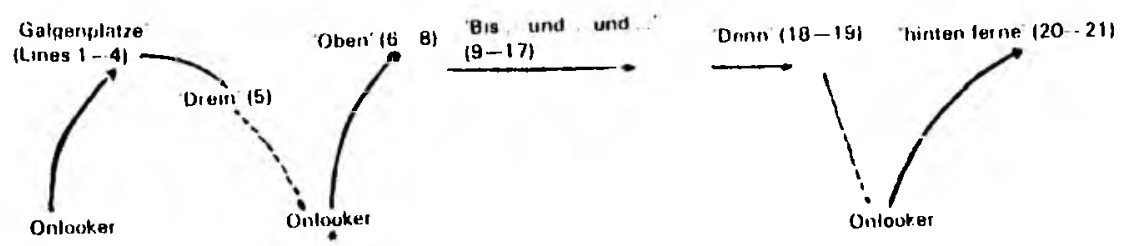

In lines I - t the movement is lrom lhe onlooker to the secenic backgeound of 
the poetic "play": line 5 hrings the eye to concentrate on one aspect within the mass serene. While stanza two direces the reader's vision to the happening in the distance once more ("Nher oben"). the thirel stanza turns the visual forus from the generalizalion ol the mass impression to a relailed e lose-up) betwern I wo individuals (a dialogue between the centurion and a soldies). The verb "sagte" portrays clese proximity while the bracketed description ("Heckig wie cin Seleher") is a vistlal enlargement. "The demonstrative pronom "dieser hat gesehrien" conveys the impression of spatial nearness.

Tuming to the lifth stanza and the crucial final act, one notices that spatial distance has again been created in "hinten ferne". Intra-modal analogy is revealed between the tensile element of the physical aspect and the intensity ol ihe suspense-lilled test that the implicel author puts to Christ. Neither the moloker uor the avid crowel evinces any real belicl in the miraculous restoration of the dying thirel man on the cross; and yet they hope against hope to be proved wrong (lines 15 and 18). The tensile-intensity of an expectation helel with balcel breath reacles a shocked climax in the collapse of their hopes. The miracle does not take place and fiod does not prove himsell to be ( ood; instead, Mary cries out in the clistance and the man howls and disintegrates:

"Alue hinten forne sehrie Maria und er selloer briille und ierfiel".

It is revelatory that the fluctuating distance of time and place is further extended in the psychic aspece of the poem. Although leceling is the irreducible characteristic of the psychic modality, this poem is strangely insensitive ("nach dem lentigsein/lessen sich dic freicn Männer schlenken; I ängsl gevil)t ... irgend cin (iesindel himandrägen") in its conscions distancing fom personal engagement. The comolive quality is therefore one of caleulatd non-involvement. The narrator remains strangely aloof and secms lo lack lecling or imagination to experience the event sensitively.

Spatial and time distance are thus anticipatorily complemented by psychic: distance.

\subsection{The aesthetic aspect}

Allusiveness, imaginalivity and symbolical originality are positivations of the acstherie dimension in literature. Inder the title "Concifixion", the diction falls into 1 wo polarities: acknowledged eathly power (of Rome) and

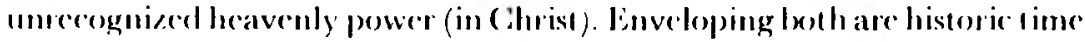
and place and the human element. 
I,ine I with its naked place ol the skull sets the scene. 'The plare of the skull is derived from Ho Aramaic term "Colgotlaa". In latin "Calvaria" also signilies skull, and is related to "Calvus", meaning bald. In German it coincides with "kahl" hence, "Calva" is scalp withoul hair (Hondriksen, 197.3: 42.5).

The worrl-group "kahlen (;algenplatze" is thus a twofold expression of the same ielea, cmphasizing the denucled barrenness of the hill and implying at lhe same time the transiloriness of lile. (On the other hand, "skull" symbolizes indestrurtibility and that which survives death. For the Christian belicver (Golgotha is synonomous with life but the sceptic's interpretation is probably diame(rically opposite, twice ascribing emptiness and nothingucss to this particular hill.

In this poem the past tense verb "verfiel" does not express the idea of volumtary sacrilice, but is specilically sceceded to port ray visible declinc and collapse, like bumt ashes disintegrating or a house of cards lalling apart. This is signilicant, as the seriptural reports all use the word "verselhed" which meaus that He gave up his Spirit. This inclicates a voluntary laying down of his life which no onc took away.

Nhhough the poem is entitled crucifivion, the symbol of the cross is never mentioned; only "das schlechle Henkern", which scmantically implies execution by hanging. The cross which is a symbol ol lile through the sacrilice of crucilixion and which is thus the roncrete crux of the whole event, is not only completely omited but also reinterpreted (here the cross (rnds in dealh).

As the aesthetic aspere is roncerned with suggestion-rich allusiveness (Secrveld, 1977: 106); it is as natural as essemtial that the authorial conlessional stand will here be revealed more convincingly and moreclearly than perhaps in other aspects.

\subsection{The all-pervading ethos}

In conclusion one final example to illust rate this pervasive ethos, must be mentioncel. "Alser hinen ferne schrie Maria". Hore, the cunjunctive "Aber" is an expression ol ilue disillusionment lollowing on the expectation shertly belene ("I)enn sic hofleon noch ein hanes Spicl"), hoping for a game and entertainment or for concrele prool that this man is (iod. When instead, "er selber brïlle und verliel" in a mulled but violent animal-like cry which ecfuated thim will man, and then collapsed, He lost his validity and is clisposed of in the minets of the speraker and most of the crowd. This collapse is not only the deray of the physical bocly but, more significantly, a disintrgyation of the crowel's possible belief in Him and above all, a linal 
negation on the part of the implicel author's opinion of the non-existeme of C.hrist, a non-acknowledgent'nt of the mediator, C:Mrist.

In this poem there is a biblical theme, olten biblical diction, fairly accurate historical narration and yet, the spirit is one of unbelief, neutralizing this crux of Christianity to just another incictent, signilying nothing.

The analysis of only three aspects of the possible fifteen has indicated and illustrated, I hope conclusively, the pervading presence of the vision of the pocm.

'Thus, if poetic communication wishes to be more than an impersonal artist speaking to an equally laceless reader; if communication clesires to become what Martin Buber (1958: 57) calls "encounter", in which the onc is sensit ized and correlative to the ontic level of feelings, at itudes and needs of the other, then the spirit of the art work, the "I" reflected in the ethos, becomes the life-giving pulse of such an encounter. 
13. ADDENDUM I ETHOS

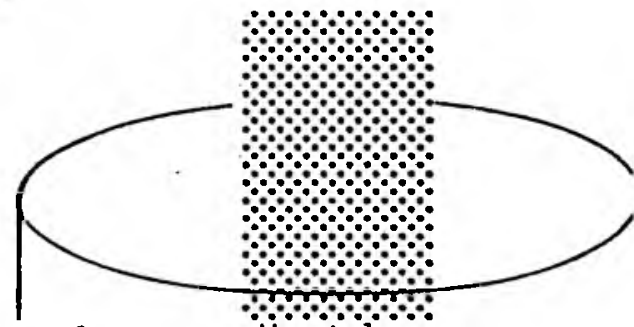

Confessional disclosure, authorial presence

Sublimity, genuineness

Density, iterative element

Relevance, appropriateness

Aesthetic thought, emblematic possibilities

Social relationships, comunicánion range

Allusiveness, 'symbolical originality

Clarity of meaning

Technical control

Intensity, cl jimaxing development, vitality

Sound, rhyme, tension, aesthetic balance

Metre, rhythm, movement

Composition

Scale

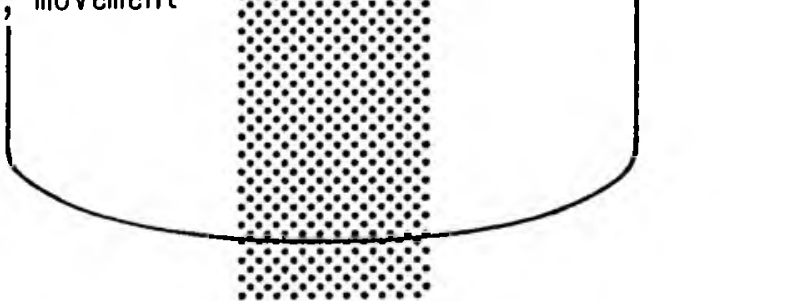

Literary Positivizations of the Dooyeweerdian Modalitles 


\section{ADDENDUM 2}

\section{KREUZIGUNG}

RAINER MARIA RILKE, Sämtliche I'erhe, Vol. I, Frankfurt/Main, InselVerlag, 1962 p. $581 / 2$

Längst geübı, zum kahlen Galgenplatze irgend ein (iesindel hiuzudrängen, liessen sich die schweren Knechte hängen, dann und wann nur eine grosse Fralze:

kehrend nach den abgelanen Drein. Aber oben war das schlechte Henkern rasch getan; und nach dem liertigsein liessen sich die freien Männer schlenkern.

Bis der eine (lleckig wie ein Selcher) sagte: Hauptmann, dieser hat geschrien. Und der I lauptmann sah vom Plerde: Welcher? und es war ihm selbst, er hälte ilı

den Elia rufen hören. Alle waren zuzuschauen voller Lust, und sic hielten, dass er niclıt verfalle, gierig ihm die ganze Essiggalle an sein schwindendes Gehust.

Derm sie holften noch ein ganzes Spicl und viefleicht den kommenden Elia. Aber hinten ferne schrie Maria, und er selber brüllte und verfiel. 


\section{CRUCIFIXION}

Long since practised to lorce any kind of rabble to the place of the gallows the heavy servants let themselves be hanged now and then only a grimace

directed to the disposed-ol three.

But above, the poor execution was quickly done; and after the conclusion the free neu shambled around swinging their arms

Until the one (spotted like a butcher) said: Captain, this one shouted and the centurion, looking from his horse: Which one? and it secmed to him that even he

had heard Elijah calling. Everybody was watching with pure pleasure and greedily held the vinegar that he might not collapse to his dwindling cough

Because they still hoped for a full show and perhaps the coming Elijah.

But behind, far off, Mary screamed and he himself howled and collapsed. 


\section{BIBLIOGRAFIE}

1. BROOKS, CLEANI'H \& WARREN R.P., 1976. Understanding Poetry. New York, Ilolt, Rinehart \& Winston.

2. BUBER, MAR'TIN, 195 . I-Thou. New York, Scribner.

3. HENDRIKSEN, WILIIAM, 1973. The Gospel of John, New Testament commentary. Edinburgh/London, The Banner of 'Thuth Thust.

4. RILKE, RAINER MARIA, 1955. Sämtliche Werke Band I. Frankfurt/Main, Insel-Verslag.

5. ROOKMAAKER, HERMAN, 1975. Modern art and the dealh of a culture. London, Inter-Varsity Press.

6. SCHNEIDER, RFINHOLD, 1956. Der Bildungsaultrag rles christlichen Dichters. Zürich, Arche.

7. SEER VELD, CALVIN, 1977. A Christian critique of art and literature, Hamilton, Ontario, Guardian press.

8. TROOST, ANDRE. 1958. Casuïtick en Situasit-ethiek. Een methodologische terreinverkenning. IJrecht, Drukkerij Libertas.

9. TROOST, ANDRÉ, 1970. Inleiding in de Wijsbegeerte. Deel I, Systematiek. Amsterdam, Vrije Universiteil.

10. VAN DER BER(;, D.J., 1974. "Enkele verskilpunte in die Christetike estetika." Tydskrif mir ('hristelike lietenskap, II.

11. WOLIERSTORFF NICHOL.AS, 1978. Art in action. Toward a Christian Aesthetic. Grand Rapids, Michigan. 